\title{
Evaluation of body image, quality of life, tactile sensitivity and pain in women with breast cancer submitted to surgical intervention
}

\author{
Juliana Nishimura Bueno' \\ Cinira Assad Simão Haddad' \\ Samantha Karlla Lopes De Almeida Rizzi' \\ Patricia Santolia Giron' \\ Gil Facina' \\ Afonso Celso Pinto Nazário'
}

1. Department of Gynecology - Federal University of São Paulo - São Paulo/SP - Brasil

http://dx.doi.org/10.1590/1806-9282.64.06.530

\section{SUMMARY}

Breast cancer is one of the most common types of tumor in the world and the most common among women. There are several treatments for breast cancer; however, the condition often can be accompanied by severe complications in a woman's life.

OBJECTIVE: o evaluate and compare body image perception, quality of life, tenderness, and pain in women with breast cancer during preoperative and postoperative periods of 30,60 and 90 days.

MATERIALS AND METHODS: We conducted a prospective longitudinal study. The patients answered the questionnaire "How I relate to my own body", EORTC QLQ-C30 and EORTC QLQ-BR23. We assessed upper limb and breast sensitivity with an esthesiometer. Patients were questioned about the presence and level of pain on a scale of 0 to 10.

RESULTS: For body image, it was possible to observe a significant difference between pre and postoperative at 30 days. There were changes in some areas of the EORTC QLQ C30 and EORTC QLQ BR23 questionnaires, such as arm and breast symptoms, social function, constipation, sexual function and satisfaction, among others. For evaluation of breast and axilla sensitivity and assessment of pain, all postoperative periods showed significant differences when compared to the preoperative period. The sensitivity of the inner region of the arm presented no significant change.

CONCLUSION: The difference found in the study shows that evaluations on all scales should be done in several periods, using a proper treatment for the changes and individuality of each patient.

KEYWORDS: Signs and symptoms. Physical therapy modalities. Body image. Breast neoplasms.

\section{INTRODUCTION}

According to the Ministry of Health, breast cancer is the leading cause of cancer-related mortality in the female population in Brazil ${ }^{1,2}$. It is also, probably, the type of cancer that causes the greatest fear in women because of its high occurrence and its psychological effects, which affect body image and quality of life ${ }^{2}$. Over the last 20 years, the techniques to treat breast cancer underwent significant changes. Nowadays, the surgeries are less invasive and the complementa- ry therapeutic treatments (radiotherapy, chemotherapy and endocrine therapy) look to establish an adequate and balanced relationship between dose and secondary effects and dose and treatment efficiency.

Among surgical techniques, there are conservative ones, such as lumpectomy and quadrantectomy, and invasive ones, such as mastectomy [2-6]. Surgical procedures can determine immediate or subsequent physical complications, such as limitation of shoulder and elbow movement amplitude (MA),

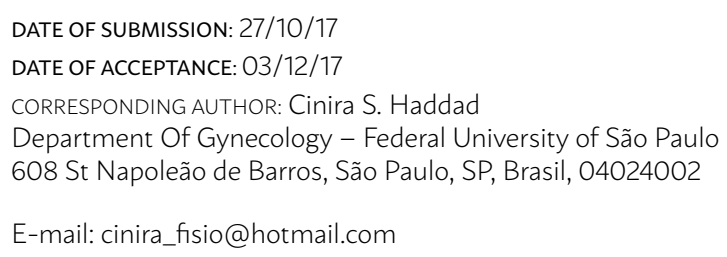


lymphedema, muscle weakness, infection, pain and paresthesia, sensitivity and functionality changes. Surgical procedures can damage the performance in daily physical activities, quality of life and women's tasks $^{2,7-9}$.

It's necessary an extensive evaluation of breast cancer treatment complications in order to adapt the best physiotherapeutic preoperative and postoperative follow-ups, as well as the best period for physiotherapeutic action.

Furthermore, a complete evaluation of these complications can support better decisions in future cases in which patients need treatment for breast cancer.

The goal of this study is to evaluate and compare body image perception, quality of life, tenderness alterations and pain presence and levels in women with breast cancer, during preoperative and postoperative periods of 30 (PO30), 60 (PO60), and 90 (PO90) days.

\section{METHODOLOGY}

We conducted a prospective longitudinal study from July 2011 to December 2013 on the perception of body image, quality of life, tenderness and pain in women diagnosed with breast cancer.

\section{Sample}

Women diagnosed with breast cancer who underwent tumor removal surgery were included. Individuals with cognitive defects that would prevent them from answering questionnaires, illiterate individuals, and individuals who did not agree with the terms of consent were excluded. Patients who did not continue to monitor the postoperative process and those who missed more than one evaluation during follow-up were also excluded. The patients were chosen at doctors' appointments at the Ambulatory of Onco-hematology of the Mastology discipline of the Gynecology Department of the Federal University of São Paulo - Unifesp.

\section{Tools}

The patients were informed about the research and signed a term of consent. After that, they answered some demographic questions and the following questionnaires: Evaluation Scale of body image "How I relate to my own body", EORTC QLQ-C30 and EORTC QLQ-BR23. The patients went through an evaluation of upper limb and breast tenderness using Monofilaments of Semmes-Weinstein from
SORRI-BAURU. They were questioned on the presence and level of pain, from 0 to 10, according to the verbal numerical rating scale (VNRS).

The questionnaire "How I relate to my own body" evaluates a woman's body image, namely the premorbid body (value assigned to the body in general) and the morbid body (value assigned to a sick person's body). The answers are obtained through the Likert scale with an assertive base. The woman is questioned about the degree of agreement in relation to aspects of her body, such as how she relates to her body and how she values her appearance. The better the condition of the patient's body image, the higher the final score on the scale ${ }^{10}$.

The EORTC QLQ C30 questionnaire is a general document referring to the quality of life with cancer. It has 30 questions that define the general quality of life, five functional scales (physical, performance, cognitive, emotional and social), three symptom scales (fatigue, pain and nausea/vomiting) and six single items (dyspnea, insomnia, loss of appetite, constipation, diarrhea and financial difficulties).

In addition, the section BR 23 from the EORTC QLQ questionnaire refers explicitly to the quality of life with breast cancer. This section has 23 questions presented on scales to measure side effects of chemotherapy, symptoms related to the upper limbs and breasts, body image and sexual function. It also includes single items that explore sexual satisfaction, hair loss distribution and future perspectives. All the score averages were transferred to a linear scale of 0 to 100 points, as described in the EORTC manual. The high scores of functional scales and overall quality of life represent, respectively, excellent function index and high quality of life, while high scores on scales of symptoms represent high levels of symptoms and problems ${ }^{11}$.

The tenderness evaluation was performed with an esthesiometer, which helps evaluate and quantify the pressure threshold in the respective skin dermatomes and aids in detecting and monitoring nerve injuries. The esthesiometer used in the evaluation is called Monofilaments of Semmes-Weinstein by SORRI-BAURU. The assessment is made by following an order of predetermined colors produced by the manufacturer according to ply and strength (grams - g). It's possible to quantify sensitivity changes in the tested area through this order.

The pain evaluation was done with the VNRS, which quantifies pain intensity by numbers and ver- 
bally refers to the patient. The VNRS is composed of 11 scores, 10 being the worst possible pain and 0 to 9 corresponding to different intermediate levels of pain. The patient can report verbally any number that they consider representative of what they are feeling ${ }^{12}$.

\section{Data collection procedure}

During preoperative (PREOP) appointment, 30 days postoperative appointment (PO30), 60 days postoperative appointment (PO60), and 90 days postoperative appointment (PO90), the patients answered some questionnaires in order to verify body image perception and quality of life. They were submitted to a sensitivity evaluation in surgery areas, i.e. the breast area, inner area of the arm, and ipsilateral axilla, with an esthesiometer.

During the test, the patient was naked and sat with their back in a neutral position, with flexed elbows and hands on their waist. The nylon filament was placed perpendicular to the skin surface and lightly pressed until it began to bend. The contact between the filament and the skin was maintained for one and a half seconds, according to the manufacturer's recommendations. Then the patient was asked to report if they were feeling anything on their skin and the location of the feeling. When the patient felt nothing, the next color was used, and the test was redone.

At the end of the procedure, all patients were asked to verbally report if they felt any pain and its intensity on a score from 0 to 10.

\section{Data analysis procedure}

Microsoft Excel 2010 and Statistica 12 were used for data analysis tests on average, standard deviation, and percentages. Matched Wilcoxon Pairs Test Software was used when comparing PREOP and PO30, PREOP and PO60, and PREOP and PO90 considering a significance level of $0.05 \%(p<0.05)$.

\section{RESULTS}

A total of 180 women were evaluated. Twelve of them were excluded for not keeping up with the postoperative monitoring and two because of death. Thus, the study was composed of 166 patients with an average age of 59 years.

Regarding the evaluation of body image, we noticed that without PREOP most of the patients had an adequate body image perception and only a small portion had very low body image. All evaluations presented the same follow-up; only at PO30 was there a statistically significant difference.

For the evaluation of the quality of life with the EORTC QLQ C30 questionnaire, we can see a significant alteration in Table I.

TABLE I. RESULTS OF EORTC QLQ C3O. AVERAGE, STANDARD DEVIATION AND WILCOXON TEST ON A COMPARISON OF PREOP WITH OTHER PERIODS, CONSIDERING P<0,05

\begin{tabular}{|c|c|c|c|}
\hline Periods & Average & $\begin{array}{l}\text { Standard } \\
\text { Deviation }( \pm)\end{array}$ & $\begin{array}{l}\text { Comparison } \\
\text { with PREOP } \\
\text { by Wilcoxon } \\
\text { test }(p<0.05)\end{array}$ \\
\hline \multicolumn{4}{|c|}{ Physical Function } \\
\hline PREOP & 84.2 & 18.5 & - \\
\hline PO30 & 82.7 & 19.3 & 0.41 \\
\hline P060 & 86.5 & 17.0 & * 0.04 \\
\hline PO90 & 86.2 & 17.6 & 0.18 \\
\hline
\end{tabular}

\begin{tabular}{l|l|l|l}
\hline Emotional Function & \multicolumn{3}{l}{} \\
\hline PREOP & 62.1 & 29.9 & - \\
\hline PO30 & 71.2 & 28.7 & ${ }^{*}<0,001$ \\
\hline PO60 & 73.6 & 29.2 & ${ }^{*}<0,001$ \\
\hline PO90 & 71.9 & 28.8 & ${ }^{*}<0,001$ \\
\hline
\end{tabular}

Cognitive Function

\begin{tabular}{l|l|l|l}
\hline PREOP & 77.9 & 26.2 & - \\
\hline PO30 & 82.1 & 25.8 & ${ }^{*} 0.01$ \\
\hline PO60 & 79.6 & 26.1 & 0.48 \\
\hline PO90 & 79.9 & 27.4 & 0.61 \\
\hline
\end{tabular}

\begin{tabular}{l|l|l|l}
\hline \multicolumn{3}{l|}{ Social Function } & \multicolumn{3}{l|}{ P } \\
\hline PREOP & 88.2 & 21.7 & - \\
\hline PO30 & 82.7 & 28.4 & ${ }^{*} 0.01$ \\
\hline PO60 & 90.2 & 21.2 & 0.49 \\
\hline PO90 & 89.3 & 22.5 & 0.41 \\
\hline
\end{tabular}

Nausea e Vomit

\begin{tabular}{l|l|l|l}
\hline PREOP & 5.8 & 15.4 & - \\
\hline PO30 & 5.0 & 15.5 & 0.28 \\
\hline P060 & 7.8 & 19.4 & 0.31 \\
\hline P090 & 11.4 & 22.3 & ${ }^{*} 0.005$ \\
\hline
\end{tabular}

Appetite Loss

\begin{tabular}{l|l|l|l}
\hline PREOP & 16.2 & 31.8 & - \\
\hline PO30 & 10.2 & 25.7 & ${ }^{*} 0.02$ \\
\hline P060 & 11.9 & 27.7 & 0.19 \\
\hline PO90 & 15.7 & 30.5 & 0.63 \\
\hline
\end{tabular}

Constipation

\begin{tabular}{l|l|l|l}
\hline PREOP & 20.2 & 35.1 & - \\
\hline PO30 & 26.6 & 38.0 & 0.06 \\
\hline P060 & 22.8 & 35.1 & 0.36 \\
\hline P090 & 27.4 & 38.7 & ${ }^{*} 0.03$ \\
\hline
\end{tabular}

Table I: \pm : Standard deviation - the extension of deviation on the average; PREOP: the preoperative period before surgery; $\mathrm{PO} 30$ : 30 days postoperative surgery; $\mathrm{PO} 60$ : 60 days postoperative surgery; PO90: 90 days postoperative surgery ${ }^{*}$ Wilcoxon test considering $\mathrm{p}<0.05$ in a comparison between PREOP and PO30/PO60/PO90. 


\section{CHART I. EVALUATION OF SENSIBILITY WITH ESTHESIOMETER}

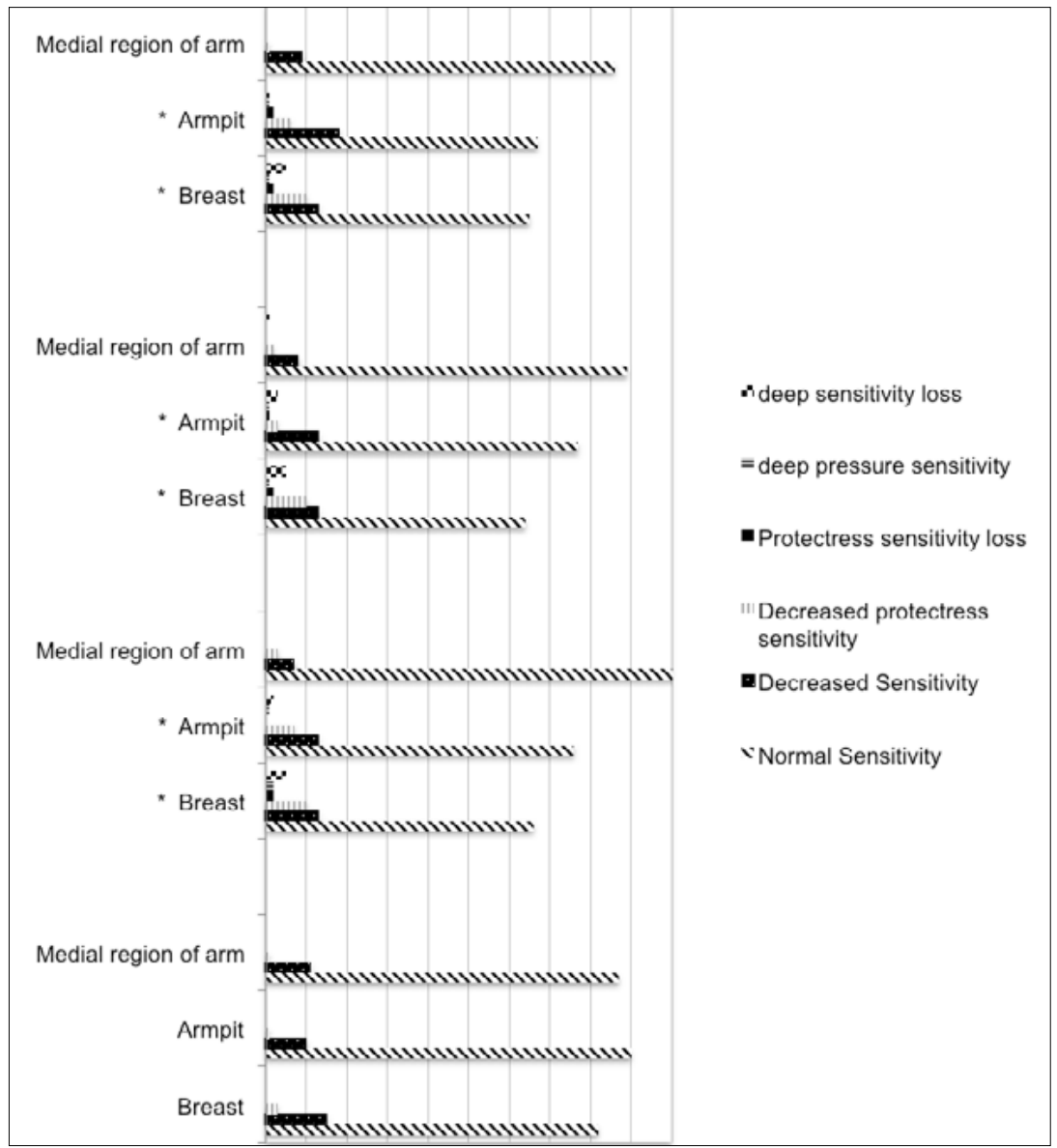

$\%$ : percentage of total number of patients; PREOP: preoperative period before surgery; PO30: 30 days postoperative surgery; PO60: 60 days postoperative surgery; P090: 90 days postoperative surgery; ${ }^{*}$ Wilcoxon test considering $p<0.05$ in comparison between PREOP and PO30 - PREOP and PO60 - PREOP and PO90.

Table II shows statistically significant alterations using the EORTC QLQ BR23 for evaluation of the quality of life. We can see the sensitivity evaluation on Chart I.

The pain evaluation with VNRS showed a statistically significant increase at all periods, PO30, PO60, and PO90, with $\mathrm{p}<0.001$ when compared to PREOP.

\section{DISCUSSION}

Several changes after breast cancer removal surgery can be seen at different times throughout the postoperative period. Thus, this type of cancer can affect women on a biopsychosocial scale ${ }^{2}$.

Body image is considered a multidimensional phenomenon, because it involves physiological, psychological, and social aspects. It also affects emotion, thoughts, and the way people relate to each other ${ }^{13-15}$.

Women go through an important process of re- shaping their body image when they deal with breast cancer due to the various changes that disease and its treatment can cause to her body and mind ${ }^{7,8,14,15}$.

This fact can be observed in our study, which showed a statistically significant decrease in body image at PO30 in comparison to PREOP. However, this study shows similar body image perception at preoperative evaluation and at the 60- and 90-day postoperative assessments. That similarity leads us to believe that patients tend to improve body image perception sometime after the surgery.

The complications from breast cancer treatment are often related to changes in the patient's quality of life $^{16}$. In our study, we could see alterations in some scales of EORTC QLQ C30 and EORTC QLQ BR23. On EORTC QLQ BR23, the scales of breast cancer symptoms and arm symptoms presented better results at PO30 and PO60 when compared to PREOP.

Studies that evaluate the quality of life also saw 
TABLE II. RESULTS OF EORTC QLQ BR23. AVERAGE, STANDARD DEVIATION AND WILCOXON TEST ON A COMPARISON OF PREOP WITH OTHER PERIODS, CONSIDERING $P<0.05$

\begin{tabular}{|c|c|c|c|}
\hline Period & Average & $\begin{array}{l}\text { Standard } \\
\text { Deviation( }( \pm)\end{array}$ & $\begin{array}{l}\text { Comparison with } \\
\text { PREOP by Wilcox- } \\
\text { on test }(p=<0.05)\end{array}$ \\
\hline \multicolumn{4}{|c|}{ Body Image } \\
\hline PREOP & 84.5 & 23.4 & - \\
\hline PO30 & 80.6 & 26.8 & ${ }^{*} 0.02$ \\
\hline P060 & 86.4 & 22.6 & 0.65 \\
\hline PO90 & 83.6 & 25.4 & 0.7 \\
\hline \multicolumn{4}{|c|}{ Sexual Function } \\
\hline PREOP & 75.2 & 28.6 & - \\
\hline PO30 & 84.7 & 22.4 & ${ }^{*}<0.001$ \\
\hline PO60 & 78.1 & 26.8 & 0.202 \\
\hline PO90 & 74.6 & 27.5 & 0.87 \\
\hline \multicolumn{4}{|c|}{ Sexual Satisfaction } \\
\hline PREOP & 41.9 & 37.0 & - \\
\hline PO30 & 62.4 & 34.5 & ${ }^{*}<0.001$ \\
\hline P060 & 45.3 & 33.8 & 0.13 \\
\hline PO90 & 45.8 & 34.8 & 0.13 \\
\hline \multicolumn{4}{|c|}{ Future Perspectives } \\
\hline PREOP & 44.4 & 40.5 & - \\
\hline $\mathrm{PO} 30$ & 52.0 & 40.3 & ${ }^{*} 0.02$ \\
\hline PO60 & 57.3 & 38.2 & ${ }^{*}<0.001$ \\
\hline PO90 & 57.7 & 40.2 & ${ }^{*}<0.001$ \\
\hline \multicolumn{4}{|c|}{ Breast Symptoms } \\
\hline PREOP & 10.7 & 14.7 & - \\
\hline PO30 & 23.0 & 22.1 & ${ }^{*}<0.001$ \\
\hline P060 & 15.6 & 18.7 & * 0.007 \\
\hline PO90 & 14.3 & 19.1 & 0.14 \\
\hline \multicolumn{4}{|c|}{ Arm Symptoms } \\
\hline PREOP & 11.2 & 18.6 & - \\
\hline PO30 & 20.5 & 20.6 & ${ }^{*}<0.001$ \\
\hline P060 & 16.8 & 21.3 & ${ }^{\star} 0.003$ \\
\hline PO90 & 15.5 & 20.8 & ${ }^{*} 0.01$ \\
\hline
\end{tabular}

Table II: Standard deviation - the extension of deviation on the average; PREOP: the preoperative period before surgery; PO30: 30 days postoperative surgery; PO60: 60 days postoperative surgery; PO90: 90 days postoperative surgery *Wilcoxon test considering $\mathrm{p}<0.05$ on a comparison between PREOP and PO30/PO60/PO90.

alterations in some aspects. Lahoz et al. ${ }^{16}$, for example, saw more significant risks in the physical aspects, pain and vitality.

We also observed that the social function scale of EORTC QLQ C30 and the body image scale EORTC QLQ BR23 worsened significantly at PO30 compared to the preoperative period.

Confirming these results, some authors say that the topics of body image and quality of life can be profoundly influenced by medical issues. Surgical procedures can make a woman feel less attractive and start worrying about her body image. Surgery can also lead to loss of sensitivity on the breast area, intensifying changes in body image and woman's quality of life ${ }^{13,17,18}$.

In our study, the scales of emotional function on the EORTC QLQ C30 and future perspectives on the EORTC QLQ BR23 had significantly better results in the three postoperative periods than in PREOP.

In addition, the scales of cognitive function and symptoms of loss of appetite on the EORTC QLQ $\mathrm{C} 30$ and the scales of sexual function and satisfaction on the EORTC QLQ BR23 got significantly better results at PO30 than at PREOP, and the scale of physical function was significantly better at PO60 than at PREOP. These facts can be justified by the same factor in Brandberg et al. ${ }^{19}$, in which, due to tumor removal, the patient sees themselves free from the disease and improve in some aspects.

Sensitivity alterations also can be found in a significant number of women after breast cancer treatment ${ }^{20}$.

We found worse results of sensitivity evaluation in this study, in which all the postoperative had a statistically significant alteration of $p<0.001$ in relation to PREOP.

Santos et al. ${ }^{20}$ conducted a sensitivity evaluation with a Semmes-Weinstein esthesiometer on the intercostobrachial nerve in 94 women. The result showed a decrease of sensitivity in nerve dermatome intercostal ipsilateral after surgery.

Among all postoperative symptoms for breast cancer, pain is another common one. Pain in the arm and ipsilateral shoulder that persists six months or more after the surgical treatment has been reported in $25-60 \%$ of cases ${ }^{21}$. On postoperative, the present study showed pain in $45.8 \%$ of patients at PO30, $41.6 \%$ at $\mathrm{PO} 60$ and $39.7 \%$ at PO90, indicating an association with the information described above by Chiu et al. ${ }^{21}$ and Ferreira et al..$^{22}$.

In the present study, it was possible to verify through the VNRS pain evaluation a statistically significant increase in all periods (PO30, PO60, and PO90) with $\mathrm{p}<0.001$ when compared to PREOP. The increasing values mean the pain was higher, that is, the symptoms got worse during postoperative periods.

For Batiston and Santiago ${ }^{23}$, pain has a multifactorial etiology and may be caused by nerve damage, psychological distress, reduced shoulder range of motion, muscle weakness and lymphedema.

In this study, sensitivity deficits as well as some aspects of quality of life and body image also present- 
ed changes that can be related to pain. In the same way, Andrade et al. ${ }^{24}$ mentioned that a negative body image could be associated with pain symptoms. However, even though our study didn't make a statistical comparison between pain and body image, these two topics are similar when monitored.

Lahoz et al. ${ }^{16}$ mention complications such as lymphedema, pain, paresthesia, decreased muscle strength and decreased range of motion in the involved member are often observed and reported by women who had breast operations. These complications deserve attention because they interfere in the quality of life.

Thus, a multidisciplinary approach to breast cancer is necessary, in which physiotherapy must be focused on general prevention, mainly the maintenance or restoration of mobility and functional capacity of the arm, preventing the patient from adopting defensive positions and other complications.

In short, we can observe that several alterations caused by breast cancer treatment are connected, which means that each can cause the onset and worsening of the other. An evaluation of all aspects and scales of a patient with breast cancer has to be conducted at several points during treatment. Moreover, it is important to remember that the evaluator's and the patient's individual peculiarities must be considered in order to accurately diagnose and treat changes in the patient.

Through the use of questionnaires, it is possible to identify some aspects that would go unnoticed at a succinct evaluation. Although the instruments used are sometimes extensive, they are necessary because they help guide the clinical and multidisciplinary treatment of patients.

\section{CONCLUSION}

The patient's body image changed after breast cancer surgery. There were worse results at 30 days postoperative compared to the preoperative evaluation.

The quality of life was altered in some aspects measured by the EORTC QLQ C30 questionnaire. It was possible to see improved physical function, emotional function and cognitive function after the surgery. However, there was a significant decline in social function, loss of appetite, nausea symptoms and spew, and constipation. The body image, and breast and arm symptoms evaluated by the EORTC QLQ BR23 questionnaire deteriorated significantly at 30 days postoperative. The sexual satisfaction, function, and its perspectives presented better results at postoperative.

It was possible to notice significantly worse results in sensitivity and pain after surgery.

\section{RESUMO}

O câncer de mama é um dos tipos mais comuns de tumores no mundo e o tipo mais comum entre as mulheres. Existem tratamentos severos para o câncer de mama, no entanto, em muitos casos, podem ser acompanhados por complicações sérias para a vida da muIher. OBJETIVO: Avaliar e comparar a percepção da imagem corporal, a qualidade de vida, a sensibilidade e a dor em mulheres com câncer de mama nos períodos pré-operatório e pós-operatório de 30, 60 e 90 dias. MÉTODOS: Foi realizado um estudo longitudinal prospectivo. Os pacientes responderam ao questionário "Como me relaciono com meu próprio corpo", o EORTC QLQ-C3O e o EORTC QLQ-BR23. Fizemos uma avaliação da sensibilidade do membro superior e da mama com um estesiômetro. Os pacientes foram questionados sobre a presença de dor e seu nível em uma escala de 0 a 10. RESULTADOS: Para a imagem corporal, foi possível observar uma diferença significativa entre o pré e pós-operatório de 30 dias. Mostrou mudanças em algumas áreas dos questionários EORTC QLQ C30 e EORTC QLQ BR23, como sintomas de braço e mama, função social, constipação e função sexual e satisfação, entre outros. Para avaliação da sensibilidade mamária e axilar e avaliação da dor, todos os períodos de pós-operatório apresentaram diferenças significativas quando comparados ao período pré-operatório. A sensibilidade da região interna do braço não apresentou mudanças significativas. CONCLUSÃO: A diferença encontrada no estudo mostra que as avaliações em todas as escalas devem ser feitas em vários períodos, utilizando um tratamento adequado que enfrente as mudanças e a individualidade de cada paciente.

PALAVRAS CHAVE: Sinais e sintomas. Modalidades de fisioterapia. Imagem corporal. Neoplasias da mama.

\section{REFERENCES}

1. Ministério da Saúde, Instituto Nacional de Câncer José Alencar Gomes da Silva (INCA). Incidence of cancer in Brazil. Available from: http:// www.saude.sp.gov.br/resources/ses/perfil/gestor/homepage/outros-destaques/estimativa-de-incidencia-de-cancer-2014/estimativa_cancer_24042014.pdf Accessed on: 15 March 2016.

2. Ministério da Saúde, Instituto Nacional de Câncer José Alencar Gomes da Silva (INCA). Diretrizes para a detecção precoce do câncer de mama no
Brasil. Available from: http://www1.inca.gov.br/inca/Arquivos/livro_deteccao_precoce_final.pdf Accessed on: 15 March 2016.

3. Camargo MC, Marx AG. Reabilitação física no câncer de mama. São Paulo: Roca; 2000.

4. Tiezzi DG. Conservative surgery in breast cancer. J Obstet Gynecol. 2007;29(8):428-34.

5. Velloso FSB, Barra AA, Dias RC. Morbidade de membros superiores e 
qualidade de vida após a biópsia de linfonodo sentinela para o tratamento do câncer de mama. Rev Bras Oncol. 2009;55(1):75-85.

6. Velloso FS, Barra AA, Dias RC. Functional performance and quality of life after sentinel lymph node biopsy of breast cancer. Rev Bras Fisioter. 2011;15(2):146-53.

7. Panobianco MS, Mamede MV. Complications and incidents associated with arm edema in the first 3 months after mastectomy. Rev Lat Am Enfermagem. 2002;10(4):544-51.

8. Jammal MP, Machado ARM, Rodrigues LR. Fisioterapia na reabilitação de mulheres operadas por câncer de mama. Mundo Saúde. 2008;32(4):506-10

9. Mesquita CF. Perfil das mulheres encaminhadas à fisioterapia no pós-operatório de câncer de mama [Dissertação de Mestrado]. Rio de Janeiro: Fundação Oswaldo Cruz; 2010.

10. Tapadinhas AR, Palhinhas P, Gouveia P. Validação da escala de imagem corporal "como me relaciono com o meu corpo". Estudo com uma amostra de mulheres com cancro da mama. In: 60 Congresso Nacional de Psicologia da Saúde. Lisboa; 2006. Atas. p.333-40.

11. Alegrance FC, Souza CB, Mazzei RL. Qualidade de vida e estratégias de enfrentamento em mulheres com e sem linfedema pós-câncer de mama. Rev Bras Cancerol. 2010;56(3):341-51.

12. Soares EW, Nagai HM, Bredt LC, Cunha AD Jr, Andradre RJ, Soares GV. Morbidity after conventional dissection of axillary lymph nodes in breast cancer patients. World J Surg Oncol. 2014;12:67.

13. Pikler $V$, Winterowd $C$. Racial and body image differences in coping for women diagnosed with breast cancer. Health Psychol. 2003;22(6):632-7.

14. Oliveira CL, Sousa FPA, Garcia CL, Mendonça MRK, Menezes IRA, Brito Junior FE. Câncer e imagem corporal: perda da identidade feminina. Rev Rene. 2010;11:53-60.

15. Santos DB, Vieira EM. Body image of women with breast cancer: a systematic review of the literature. Cien Saude Colet. 2011;16(5):2511-22.
16. Lahoz MA, Nyssen SM, Correia GN, Garcia APU, Driusso P. Capacidade funcional e qualidade de vida em mulheres pós-mastectomizadas. Rev Bras Cancerol. 2010;56(4):423-30.

17. Collin KK, Liu Y, Schootman M, Aft R, Yan Y, Dean G, et al. Effects of breast cancer surgery and surgical slide effects on body image over time. Breast Cancer Res Treat. 2011;126(1):167-76.

18. Keskin G, Gumus AB. Turkish hysterectomy and mastectomy patients: depression, body image, sexual problems and spouse relationships. Asian Pac J Cancer Prev. 2011;12(2):425-32.

19. Brandberg $Y$, Sandelin K, Erikson S, Jurell G, Liljegren A, Lindblom $A$, et al. Psychological reactions, quality of life and body image after bilateral prophylactic mastectomy in women at high risk for breast cancer: a prospective 1-year follow-up study. I Clin Oncol. 2008;26(24):3943-9.

20. Santos MS, Panobianco MS, Mamede MV, Meirelles MC, Barros VM. Tactile sensibility in arm of women subjected to the axillary lymph node dissection for breast cancer. Rev Bras Ginecol Obstet. 2009;31(7):361-6.

21. Chiu M, Bryson GL, Lui A, Watters JM, Taljaard M, Nathan HJ. Reducing persistent postoperative pain and disability 1 year after breast cancer surgery: a randomized, controlled trial comparing thoracic paravertebral block to local anesthetic infiltration. Ann Surg Oncol. 2014;21(3):795-801.

22. Ferreira BP, Pimentel MD, Santos LC, Flora W, Gobbi H. Morbidity after sentinel node biopsy and axillary dissection in breast cancer. Rev Assoc Med Bras (1992). 2008;54(6):517-21.

23. Batiston AP, Santiago SM. Fisioterapia e complicações físico-funcionais após tratamento cirúrgico do câncer de mama. Fisioterapia e Pesquisa. 2005;12(3):30-5.

24. Andrade FA, Pereira LV, Sousa FA. Pain measurement in the elderly: a review. 2006;14(2):271-6.

25. Cezar K, Nascimento APC. Qualidade de vida de pacientes pós-mastectomizadas em reabilitação oncológica. UNOPAR Cient Ciênc Biol Saúde. 2014;16(1):29-32 